\title{
Perbedaan Daya Hambat Kefir Susu Kambing dengan Kefir Susu Sapi Terhadap Escherichia coli Secara in vitro
}

\author{
Qonita Syafrina ${ }^{1}$, Roslaili Rasyid ${ }^{2}$, Linosefa ${ }^{3}$ \\ ${ }^{1}$ Profesi Dokter Fakultas Kedokteran Universitas Andalas, Padang \\ ${ }^{2}$ Bagian Mikrobiologi Fakultas Kedokteran Universitas Andalas, Padang \\ ${ }^{3}$ Bagian Mikrobiologi Fakultas Kedokteran Universitas Andalas, Padang
}

\author{
A B S T R A C T
}

\begin{abstract}
Latar Belakang. Kefir merupakan suatu produk susu fermentasi. Komposisinya didominasi oleh bakteri asam laktat (BAL) dan zat metabolit sekunder bakteriosin yang bersifat antibakteri terhadap bakteri patogen seperti Escherichia coli.

Objektif. Penelitian ini bertujuan untuk membandingkan daya hambat dari kefir susu kambing dan kefir susu sapi terhadap Escherichia coli dengan menilai Kadar Hambat Minimal (KHM) dan Kadar Bunuh Minimal (KBM).
\end{abstract}

Metode. Penelitian dilakukan dengan teknik dilusi desain Rancangan Acak Lengkap. Kefir diencerkan menjadi Tanpa Pengenceran, Pengenceran 1/2, Pengenceran 1/4, Pengenceran 1/8, Pengenceran 1/16, dan kontrol. Daya hambat berupa nilai KHM dan KBM ditentukan dengan menghitung manual jumlah koloni bakteri yang tumbuh. Analisis data menggunakan uji Kruskal-Wallis dan post hoc dengan uji Mann-whitney.

Hasil. Jumlah koloni baru E.coli dengan pemberian kefir susu kambing pada pengenceran 1/16, 1/8, 1/4, dan tanpa pengenceran secara berurut 114; 50;60;0,03 CFU/ml, dibandingkan dengan kontrol $470.000 \mathrm{CFU} / \mathrm{ml}$. Hasil pada pemberian kefir susu sapi secara berurut, 139,$5 ; 5 ; 7,5 ; 0$ $\mathrm{CFU} / \mathrm{ml}$, dibandingkan dengan kontrol $1.670 .000 \mathrm{CFU} / \mathrm{ml}$. Hasil dari jumlah koloni E.coli pada kefir susu kambing dan susu sapi terdapat perbedaan yang signifikan selain pada Pengenceran 1/16. KHM dan KBM ditemukan pada kedua kefir dengan persentase penurunan jumlah bakteri $>99,9 \%$ di tiap kelompok. Berdasarkan daya hambat KHM dan KBM tidak ada perbedaan antara kefir susu sapi dan kefir susu kambing.

Kesimpulan. Tidak terdapatnya perbedaan daya hambat berupa KHM dan KBM antara kefir susu kambing dan kefir susu sapi, namun secara rerata kefir susu sapi lebih baik dalam menghambat pertumbuhan E.coli.

Kata kunci: kefir, Escherichia coli, susu kambing, susu sapi, antibakteri

\begin{abstract}
Background. Kefir is a fermented milk. The composition dominated by lactic acid bacteria (LAB) and secondary metabolites bacteriocins with antibacterial activity against pathogenic bacteria such as Escherichia coli.
\end{abstract}

Objective. This study aims to compare antibacterial effect goat milk kefir and cow milk kefir against growth of E.coli by assessing Minimum Inhibitory Concentration (MIC) and Minimum Bactericidal Concentration (MBC).

Methods. This research was carried out by dilution technique with completely randomized design. Kefir diluted into, Without Dilution, 1/2 dilution, 1/4 dilution, 1/8 dilution, 1/16 dilution, and control. MIC and MBC values as antibacterial effect determined by manually counting bacterial colonies. Data were analyzed by Kruskal-wallis test and post hoc by Mann-whitney test.

Results. Total E.coli colony count with administration goat milk kefir in each group of $1 / 16$ dilution, 1/8, 1/4, without dilution sequentially are $114 ; 50 ; 60 ; 0,03 \mathrm{CFU} / \mathrm{ml}$, compared to control $470.000 \mathrm{CFU} / \mathrm{ml}$. Result of cow milk kefir by dilution sequentially are 139,$5 ; 5 ; 7,5 ; 0 \mathrm{CFU} / \mathrm{ml}$, compared to control 1.670.000 CFU/ml. Result of E.coli count between goat milk kefir and cow milk kefir have a significant differences, except in 1/16 dillution. MIC and MBC present on both kefir with decreasing percentage total colony count $>99,9 \%$ in every groups. Based on antibacterial effect MIC and MBC there are no differences between goat milk kefir and cow milk kefir.

Conclusion. There are no differences on antibacterial activities shown as MIC and MBC values between goat milk kefir and cow milk kefir, but the mean result showed cow milk kefir better inhibit E.coli growth.

Keywords: kefir, Escherichia coli, goat milk, cow milk, antibacterial 


\section{Apa yang sudah diketahui tentang topik ini?}

Kefir sebagai minuman probiotik mengandung bakteri asam laktat (BAL), bakteri asam asetat (BAA) dan zat metabolit bakteriosin, hidrogen peroksida yang bersifat antibakteri terhadap bakteri patogen.

CORRESPONDING AUTHOR

Phone: +6282211164688

E-mail: qonita.syafrina@gmail.com
Apa yang ditambahkan pada studi ini?

Perbedaan penggunaan medium susu kefir terhadap aktivitas antibakteri terhadap Escherichia coli.

ARTICLE INFORMATION

Received: August $4^{\text {th }}, 2020$

Revised: April 18 ${ }^{\text {th }}, 2021$

Available online: May $27^{\text {th }}, 2021$

\section{Pendahuluan}

Produk susu fermentasi sebagai probiotik memiliki manfaat bagi kesehatan bagi yang mengkonsumsinya secara rutin. Probiotik adalah mikroba hidup yang apabila dikonsumsi dalam jumlah yang adekuat dapat memberikan manfaat bagi kesehatan. ${ }^{1}$ Kefir adalah susu fermentasi dengan rasa asam dan konsistensi kental yang berasal dari Kaukasus. Walaupun tidak sepopuler produk susu fermentasi lainnya seperti yogurt dan keju, kefir sudah dikonsumsi selama 100 tahun dan dipercaya manfaat kesehatannya. Perbedaan dengan susu fermentasi lainnya yaitu kefir membutuhkan butir atau biji kefir (kefir grain) sebagai starter dalam proses fermentasinya. ${ }^{2}$

Komposisi kefir didominasi oleh bakteri asam laktat (BAL), bakteri asam asetat dan khamir (yeast). Mikroorganisme yang terdapat dalam kefir terdiri atas organisme seperti Lactobacillus kefir, Lactobacillus delbruecki, Lactococcus, Acetobacter sp, dan Saccharomyces sp. BAL pada kefir menghasilkan berbagai substansi menguntungkan seperti bakteriosin, hidrogen peroksida, serta asam organik lainnya.3,4

Kefir secara tradisionalnya dibuat menggunakan produk susu, seperti susu sapi atau produk susu hewan lainnya, hingga penggunaan bahan dasar berupa buah di daerah yang kesulitan untuk mendapatkan susu hewan. ${ }^{5}$ Perbedaan penggunaan medium dasar susu yang digunakan dapat mempengaruhi kualitas dan kandungan dari hasil kefir tersebut. ${ }^{6}$ Penggunaan berbagai jenis medium dasar bagi probiotik akan mempengaruhi probiotik secara fungsional, seperti ketahanannya terhadap kondisi saluran pencernaan yang merusak probiotik, kemampuan untuk melekat pada epitel pencernaan dan aktivitas immunomodulatornya. Penggunaan medium susu hewani pada probiotik dapat mentoleransi kondisi pada saluran pencernaan secara lebih baik dibandingkan penggunaan medium non-hewani, hal ini terjadi karena susu

dan lemak susu menjadi buffer yang melindungi probiotik pada kondisi yang tidak menguntungkan dengan cara mengurangi paparan langsung yang akan merusak probiotik. Penggunaan medium susu lebih baik sebagai medium dasar probiotik. ${ }^{7}$

Pada proses produksi, penggunaan biji kefir yang berbeda akan menghasilkan kefir dengan kualitas maupun komposisi yang berbeda. Komposisi mikroba utama pada kefir berasal dari biji kefir yang digunakan sebagai starter. Penggunaan medium dasar yang berbeda dalam membuat kefir akan mempengaruhi kualitas, kandungan, maupun daya hambatnya dalam menghambat pertumbuhan bakteri. Hal ini disebabkan karena bakteri asam laktat (BAL) pada kefir tidak hanya didapatkan dari biji kefir itu sendiri, tetapi juga dihasilkan oleh medium dasar yang digunakan pada saat proses fermentasi berlangsung, yaitu dari laktosa yang terkandung dalam jenis susu sebagai medium fermentasinya. Kadar laktosa yang berbeda dari susu kambing dan susu sapi yang akan menyebabkan perbedaan BAL pada hasil akhir kefir dari kedua susu tersebut.6,8

Konsumsi kefir telah banyak dikaitkan dengan berbagai macam keuntungan bagi kesehatan. Beberapa keuntungannya adalah sebagai antitumor, antifungal, antibakteri, imunomodulator atau proteksi epitel, anti inflamasi, membantu proses penyembuhan, serta memiliki aktifitas antioksidan. Kefir sebagai antibakteri memiliki kemampuan daya hambat terhadap berbagai macam bakteri dengan terjadinya kematian sel bakteri atau bakteriolisis. Proses bakteriolisis yang terjadi pada bakteri patogen dipengaruhi oleh berbagai komposisi kefir yang bersifat antibakteri seperti BAL, hidrogen peroksida, dan bakteriosin. ${ }^{9-12}$

Salah satu penelitian terhadap daya hambat dan aktivitas antibakteri dari kefir yang dilakukan dengan metode disk diffusion terhadap bakteri patogen secara luas maupun spesies jamur, 
memiliki hasil yaitu, kefir ditemukan memiliki sifat antimikrobial yang setara dengan ampicilin, azithromycin, ceftriaxone, amoxicillin, dan ketoconazole. ${ }^{11}$ Berdasarkan penelitian Suhartanti, dalam membandingkan aktivitas anti bakterial kefir susu kambing dan kefir susu sapi terhadap Bacillus cereus dan Staphylococcus aureus, tidak ada perbedaan bermakna antara kemampuan antibakteri kefir susu sapi dan kefir susu kambing. Hasil yang didapat dari metode disk diffusion tersebut, jika dilihat rata-rata dari kedua kelompok antara kefir susu sapi dan kefir susu kambing, rata-rata terbesar secara umum berdasarkan diameter zona hambatnya adalah kefir susu kambing, sehingga susu kambing lebih cocok digunakan sebagai medium fermentasi pembuatan kefir.6,7

Bakteri patogen pada makanan yang umum menjadi penyebab berbagai masalah kesehatan salah satunya adalah Escherichia coli. E.coli merupakan salah satu jenis bakteri Gram negatif yang merupakan mikroorganisme komensal dalam saluran pencernaan manusia. E. coli hidup secara simbiosis mutualisme dengan pejamunya dan jarang menimbulkan penyakit. E. coli merupakan patogen yang paling umum pada manusia maupun hewan yang menyebabkan berbagai penyakit. Hal tersebut disebabkan karena terdapat juga klon E.coli yang memiliki faktor virulensi spesifik dan menyebabkan infeksi. Berdasarkan klasifikasinya, E.coli memiliki beberapa tipe patogenik. Setidaknya ada 7 macam enteric E.coli dan 3 macam extraintestinal E.coli. ${ }^{14}$

Masalah kesehatan yang dapat ditimbulkan oleh E.coli antara lain diare, muntaber, infeksi saluran kemih dan masalah pencernaan lainnya. Kondisi-kondisi seperti ini dapat terjadi bila meningkatnya jumlah bakteri tersebut di saluran cerna, menurunnya daya tahan tubuh, terganggunya barier gastrointestinal normal atau jika bakteri tersebut berada di luar usus.

Kefir sebagai probiotik bisa menjadi pendekatan profilaksis bagi beberapa infeksi dari E. coli. Berdasarkan studi bahwa pemberian probiotik dapat mengoptimalkan flora usus guna menghambat pertumbuhan bakteri patogen makanan dengan cara berkompetisi dengan bakteri patogen, salah satunya terhadap E. coli patogen. ${ }^{15}$

Dari pemaparan latar belakang diatas, penelitian ini dilakukan dengan tujuan untuk mengetahui perbedaan daya hambat dari kefir susu kambing dan kefir susu sapi terhadap Escherichia coli secara in vitro sehingga dapat memberikan informasi ilmiah mengenai aktivitas antibakteri dari kefir sebagai probiotik yang dapat dikonsumsi dan memberikan keuntungan bagi kesehatan.

\section{Metode}

Penelitian ini adalah eksperimental murni dengan menggunakan Rancangan Acak Lengkap (RAL). Dilakukan pengenceran serial terhadap kefir susu kambing dan kefir susu sapi, yaitu tanpa pengenceran; dengan pengenceran $1 / 2$; dengan pengenceran $1 / 4$; dengan pengenceran $1 / 8$; dengan pengenceran 1/16. Kontrol berupa suspensi bakteri Escherichia coli tanpa ditambahkannya kefir. Populasi penelitian ini adalah kefir, sedangkan sampel adalah kefir susu kambing dan kefir susu sapi yang diperoleh dari Rumah Susu Padang Panjang. Pengulangan dilakukan dengan rumus Federer dan didapatkan pengulangan sebanyak 4 kali pada masing-masing kefir susu kambing dan kefir susu sapi.

Kefir disentrifugasi dengan kecepatan 10.000 rpm selama 10 menit untuk mengendapkan bakteri sebagai pelet dan supernatan kefir digunakan pada penelitian ini. Supernatan kefir kemudian diencerkan secara serial untuk mendapatkan lima jenis pengenceran berbeda yang dibutuhkan. ${ }^{16,17}$ Suspensi bakteri Escherichia coli disesuaikan dengan standard Mc. Farland 0,5.

Masing-masing 0,1 $\mathrm{ml}$ dari pengenceran supernatan kefir dimasukkan ke dalam tabung reaksi dengan $1 \mathrm{ml}$ nutrient broth (NB) dan 0,1 ml suspensi bakteri.Tabung reaksi diinkubasi pada suhu $37^{\circ} \mathrm{C}$ selama 24 jam. Dalam menilai ada tidaknya pertumbuhan E. coli dilakukan dengan uji TPC (Total Plat Count) pada media agar Muller Hilton menggunakan teknik cawan sebar (spread plate). Masing-masing tabung yang berisi supernatan kefir, NB dan suspensi bakteri diencerkan dengan aquades yang berjumlah $9 \mathrm{ml}$. Pengenceran dilakukan bertahap sampai pada konsentrasi $10^{-7} \mathrm{CFU} / \mathrm{ml}$ dan kemudian divortex. Hasil dari pengenceran terakhir dari tiap konsentrasi diambil 0,1 $\mathrm{ml}$ dan diteteskan ke dalam cawan petri yg sudah berisi medium dan sampel diratakan. Setelah dikultur, cawan petri diinkubasi kembali pada suhu $37^{\circ} \mathrm{C}$ selama 24 jam. ${ }^{18,19}$

Data hasil penelitian kemudian dianalisis secara statistik yang terdiri dari uji normalitas

Qonita Syafrina 
data menggunakan uji Shapiro-wilk dan uji homogenitas varian. Jika data didapatkan tidak normal sehingga tidak memenuhi untuk dilakukannya uji parametrik sehingga dilanjutkan dengan uji secara non-parametrik menggunakan uji Kruskal-wallis untuk melihat perbedaan diantara tingkat pengenceran pada kefir susu kambing dan kefir susu sapi. Uji post-hoc dilakukan dengan uji Mann-whitney pada tiap pengenceran terhadap kontrol serta perbandingan pada tiap pengencerannya pada kefir susu kambing atau kefir susu sapi. Untuk membandingkan daya hambat kefir susu kambing dan kefir susu sapi pada tingkat pengenceran yang sama, digunakan uji Mann-whitney.

KHM dan KBM dinilai dengan cara menghitung manual jumlah pertumbuhan koloni baru dari E.coli pada cawan. Ketentuan KHM adalah Nilai pengenceran minimal kefir yang dapat menghambat $90 \%$ pertumbuhan E.coli. KBM ditentukan dengan nilai pengenceran minimal kefir yang menyebabkan penurununan konsentrasi E. coli sebesar 99,9\%.18,19

\section{Hasil}

Tabel 1 berikut memperlihatkan jumlah koloni baru E.coli yang tumbuh pada pemberian kefir susu kambing dengan berbagai pengenceran serta kontrol tanpa pemberian kefir. Peneliti mengeliminasi variabel pengenceran $1 / 2$ dari penyajian data karena didapatkan hasil pengenceran 1/2 memiliki nilai extreme.

Tabel 1. Pengaruh aktivitas daya hambat kefir susu kambing dengan berbagai pengenceran terhadap Escherichia coli.

\begin{tabular}{cc}
\hline Kefir Susu Kambing & $\begin{array}{c}\text { Jumlah Koloni Baru } \\
\text { E.coli } \\
\text { (CFU/ml) }\end{array}$ \\
\hline Pengenceran 1/16 & 114 \\
Pengenceran 1/8 & 50 \\
Pengenceran 1/4 & 60 \\
Tanpa Pengenceran & 0,03 \\
Kontrol & 470.000 \\
\hline
\end{tabular}

Nilai persentase penurunan jumlah koloni E.coli pada seluruh kefir susu kambing memiliki penurunan jumlah koloni bakteri hingga 99,9\%, sehingga dapat disimpulkan terdapat KHM dan KBM pada tiap varian tingkat pengenceran dari kefir susu kambing dengan nilai minimum pada Pengenceran 1/16.
Hasil data tersebut dilakukan uji normalitas didapatkan data normal ( $p>0,05)$, uji homogenitas dengan hasil data terdistribusi tidak homogen $(\mathrm{p}<0,05)$. Berdasarkan uji Kruskal-wallis memperlihatkan perbedaan yang signifikan antar pengenceran serta kontrol $(\mathrm{p}<0,05)$. Tabel 2 adalah hasil uji post hoc dengan uji Mann-whitney yang menguji perbedaan dari pertumbuhan koloni E.coli pada tiap varian pengenceran maupun kontrol. Hasil pada pengenceran 1/8 dan pengenceran $1 / 4$ tidak terdapat perbedaan yang signifikan $(p>0,05)$, sedangkan pada pengenceran lain dan kontrol yg dibandingkan satu sama lain terdapat perbedaan yang signifikan $(\mathrm{p}<0,05)$. Hasil post hoc dalam membandingkan seluruh tingkat pengenceran kefir susu kambing dengan kontrol pada pengenceran $1 / 16$, pengenceran $1 / 8$, pengenceran $1 / 4$, dan tanpa pengenceran yaitu secara berurut 0,$021 ; 0,021 ; 0,021 ;$ dan 0,02 .

Tabel 2. Nilai signifikansi (p) uji Post-Hoc dengan ujiMannWhitney antar masing-masing pengenceran dan kontrol pada kefir susu kambing.

\begin{tabular}{cccccc}
\hline \multicolumn{6}{c}{ Tingkat Pengenceran Kefir Susu Kambing } \\
\hline Kelompok & Kontrol & P 1/6 & P 1/8 & P1/4 & TP \\
\hline Kontrol & - & 0,021 & 0,021 & 0,021 & 0,02 \\
P 1/16 & 0,021 & - & 1,00 & 1,00 & 0,02 \\
P 1 /8 & 0,021 & 1,00 & - & 0,77 & 0,02 \\
P 1 /4 & 0,021 & 1,00 & 0,77 & - & 0,02 \\
TP & 0,02 & 0,02 & 0,02 & 0,02 & - \\
\hline
\end{tabular}

Hasil penelitian dari aktivitas daya hambat kefir susu sapi terhadap pertumbuhan E.coli dapat dilihat pada tabel 3 berikut dengan hasil kefir susu sapi menunjukkan seluruh tingkat pengenceran memiliki daya hambat berupa jumlah koloni baru E.coli yang lebih sedikit dibandingkan dengan kontrol.

Tabel 3. Pengaruh aktivitas daya hambat kefir susu sapi dengan berbagai pengenceran terhadap Escherichia coli.

\begin{tabular}{cc}
\hline Kefir Susu Sapi & $\begin{array}{c}\text { Jumlah Koloni Baru E.coli } \\
\text { (CFU/ml) }\end{array}$ \\
\hline Pengenceran 1/16 & 139,5 \\
Pengenceran 1/8 & 5 \\
Pengenceran 1/4 & 7,5 \\
Tanpa Pengenceran & 0 \\
Kontrol & 1.670 .000 \\
\hline
\end{tabular}

Nilai persentase penurunan jumlah koloni E.coli pada kefir susu sapi tanpa pengenceran tidak didapatkannya koloni baru, sehingga persentase penurunan jumlah bakteri mencapai $100 \%$, sedangkan pada tingkat pengenceran 
lainnya memiliki nilai persentase 99,99\%, maka dapat disimpulkan kefir susu sapi pada seluruh tingkat pengencerannya terdapat KHM dan KBM dengan nilai minimum pada Pengenceran 1/16.

Pengolahan data uji normalitas didapatkan data tidak normal dan hasil uji homogenitas menunjukkan data terdistribusi tidak homogen ( $p>0,05)$. Hasil uji Kruskal-wallis memperlihatkan perbedaan yang signifikan $(\mathrm{p}<0,05)$ pada setiap tingkat pengenceran kefir dan kontrol. Uji post hoc dengan uji Mann-whitney pada tabel 4 menguji tiap pengenceran dari kefir susu sapi dan kontrol dengan hasil terdapat perbedaan yang signifikan $(p<0,05)$ kecuali pada varian pengenceran $1 / 8$ terhadap pengenceran $1 / 4$ tidak terdapat perbedaan yang signifikan $(\mathrm{p}>0,05)$. Hasil post hoc dalam membandingkan seluruh tingkat pengenceran kefir susu sapi dengan kontrol pada pengenceran $1 / 16$, pengenceran $1 / 8$, pengenceran $1 / 4$, dan tanpa pengenceran yaitu secara berurut 0,$021 ; 0,018 ; 0,021$; dan 0,014 . Kesimpulan yang didapat yaitu pada seluruh tingkat pengenceran kefir susu sapi dapat menghambat pertumbuhan dari E.coli secara signifikan $(p<0,05)$.

Tabel 4. Nilai signifikansi (p) uji Post-Hoc dengan uji Mann-Whitney antar masing-masing pengenceran dan kontrol pada kefir susu sapi.

\begin{tabular}{cccccc}
\hline \multicolumn{7}{c}{ Tingkat Pengenceran Kefir Susu Kambing } \\
\hline Kelompok & Kontrol & P 1/6 & P 1/8 & P1/4 & TP \\
\hline Kontrol & - & 0,021 & 0,018 & 0,021 & 0,014 \\
P 1/16 & 0,021 & - & 0,018 & 0,021 & 0,014 \\
P 1/8 & 0,018 & 0,018 & - & 0,215 & 0,011 \\
P 1/4 & 0,021 & 0,021 & 0,215 & - & 0,014 \\
TP & 0,014 & 0,014 & 0,011 & 0,014 & - \\
\hline
\end{tabular}

Hasil penelitian menunjukkan seluruh hasil pada kefir susu kambing dan kefir susu sapi pada tiap tingkat pengencerannya memiliki KHM serta KBM. Tidak ada perbedaan daya hambat berupa nilai minimal KHM dan KBM dari kefir susu kambing dan kefir susu sapi. Total jumlah koloni E.coli dari kefir susu kambing dan kefir susu sapi berbeda sehingga dilanjutkan analisis secara statistik yang dilakukan dengan uji Mann-Whitney. Tabel 5 merupakan hasil dari perbandingan jumlah koloni E.coli pada masing-masing tingkat pengenceran untuk memperlihatkan nilai signifikansi yang berbeda-beda.
Tabel 5. Perbedaan jumlah koloni E.coli dari kefir susu kambing dengan kefir susu sapi

\begin{tabular}{cccc}
\hline \multirow{3}{*}{$\begin{array}{c}\text { Tingkat } \\
\text { Pengenceran }\end{array}$} & \multicolumn{2}{c}{$\begin{array}{c}\text { Jumlah Koloni E.coli } \\
\text { (CFU/m) }\end{array}$} & Sig.(p) \\
\cline { 2 - 4 } & $\begin{array}{c}\text { Kefir Susu } \\
\text { Kambing }\end{array}$ & $\begin{array}{c}\text { Kefir Susu } \\
\text { Sapi }\end{array}$ & \\
\hline P 1/16 & 114 & 139,5 & 0,564 \\
P 1/8 & 50 & 5 & 0,018 \\
P 1/4 & 60 & 7,5 & 0,021 \\
TP & 0,03 & 0 & 0,046 \\
\hline
\end{tabular}

Tabel 5 memperlihatkan hanya pada pengenceran $1 / 16$ hasil tidak terdapat perbedaan yang bermakna $(p>0,05)$, sedangkan pada tingkat pengenceran lainnya yaitu tanpa pengenceran, dengan pengenceran $1 / 4$, dan pengenceran $1 / 8$ menunjukkan bahwa terdapat perbedaan yang bermakna antara daya hambat kefir susu kambing dan kefir susu sapi $(p<0,05)$.

\section{Pembahasan}

Hasil dari penelitian ini menunjukkan bahwa terdapat daya hambat dari supernatan kefir susu kambing dan kefir susu sapi terhadap pertumbuhan E.coli secara in vitro. Daya hambat tampak dari jumlah koloni E.coli yang tumbuh pada masing-masing pengenceran dari kefir susu kambing maupun kefir susu sapi yang jumlahnya jauh lebih kecil dibandingkan dengan kontrol negatif tanpa kefir. Hasil penelitian ini sejalan dengan penelitian yang dilakukan oleh Sulmiyati dalam menilai aktivitas antibakteri dari kefir susu kambing terhadap E.coli dengan hasil menunjukkan aktivitas antibakteri dengan adanya daya hambat dengan zona jernih dalam penggunaan metode disk diffusion. Perbedaan penggunaan jenis bakteri gram positif dan gram negatif dapat memberikan hasil yang berbeda dalam daya hambat aktivitas antibakteri dari kefir. Dinding bakteri Gram positif yang lebih tebal bukan merupakan variabel yang mempengaruhinya, tetapi adanya membran luar sebagai barrier pada bakteri Gram negatif yang menyulitkan bakteriosin untuk menembus membran sel. Aktivitas antibakteri bakteriosin lebih sensitif terhadap bakteri Gram positif bila dibandingkan dengan bakteri Gram negatif. Kefir memiliki berbagai zat antibakteri yang dihasilkan oleh bakteri asam laktat serta bakteri asam asetat seperti, hidrogen peroksida, diasetil, asetaldehid, alkohol, dan bakteriosin. Zat-zat tersebut dapat mempengaruhi bagian-bagian vital pada sel bakteri dan bekerja dengan merusak dinding sel, 
mengubah permeabilitas membran sel, terjadinya kerusakan sitoplasma, menghambat kerja berbagai enzim dan menghambat sintesis asam nukleat protein hingga terjadinya kematian sel. $6,8,20,21,31$

Senyawa antibakteri yang terkandung memiliki beberapa sifat, antara lain dapat bersifat bakterisidal (membunuh bakteri), bakteristatik (menghambat pertumbuhan mikroba), fungisidal (membunuh kapang), fungistatik (menghambat pertumbuhan kapang, serta germisidal (menghambat germinasi spora bakteri). Penelitian ini menilai adanya sifat bakterisidal dan bakteriostatik dari kefir terhadap E.coli dengan melihat ada atau tidaknya KHM serta KBM. Kedua jenis kefir susu kambing dan kefir susu sapi menunjukkan adanya KHM dan KBM pada tiap tingkat pengencerannya dengan melihat persentase penurunan jumlah bakteri $>99,9 \%$ pada tiap pengenceran dari kefir susu kambing dan kefir susu sapi, sehingga dapat disimpulkan kefir susu kambing dan kefir susu sapi memiliki sifat bakterisidal dan bakteriostatik. ${ }^{22}$

Pola yang didapatkan pada penelitian ini tidak menunjukkan pelemahan aktivitas antibakteri dengan dilakukannya pengenceran lebih besar, tetapi tidak selalu konsisten pada tiap pengencerannya. Hal ini juga ditemukan pada penelitian yang dilakukan oleh Kim et al, dimana hasil daya hambat dari supernatan kefir memperlihatkan hasil yang berubah-ubah dalam aktivitas antibakteri kefir serta tidak membentuk pola menguat ataupun menurun. ${ }^{23}$ Supernatan dari kefir mengandung berbagai produk metabolit seperti asam organik, hidrogen peroksida, peptida, dan bakteriosin. Bakteriosin dan kompleks peptida memiliki efek antagonis intraseptik terhadap strain produktornya, sehingga dapat dikemukakan bahwa senyawasenyawa ini dapat berinteraksi sesamanya untuk meningkatkan aktivitas maupun bekerja secara antagonis terhadap aktivitas antibakterinya. Kefir menghasilkan aktivitas antibakteri yang inkonsisten dalam berbagai pengencerannya. ${ }^{24,25}$

Bakteri asam laktat pada kefir berperan sebagai antimikroba, baik melalui BAL tersebut maupun melalui produk-produk metabolit yang dihasilkannya. Asam-asam organik yang dihasilkan BAL tidak hanya efektif menurunkan pH dan bekerja pada kondisi asam, tetapi juga dapat efektif sebagai antibakteri pada $\mathrm{pH}$ mendekati netral. Pada saat terjadinya penurunan
pH yang disebabkan oleh asam organik, terjadi berbagai mekanisme yang menyebabkan terhambatnya pertumbuhan dari bakteri. Terjadinya pelepasan proton ke dalam sitoplasma bakteri sehingga $\mathrm{pH}$ di dalam membran sel menjadi sangat asam secara mendadak sehingga menyebabkan keseimbangan asam basa pada sel bakteri terganggu. Perubahan ini mengganggu transportasi nutrisi ke dalam sel serta menyebabkan metabolit internal keluar dari sel dan berakibat kematian dari sel bakteri. Produk susu fermentasi seperti kefir memiliki zat antimikroba utama dari sintesis BAL berupa substansi protein yaitu bakteriosin dengan aktivitas bakterisidal yang bersifat letal terhadap intraspesies. ${ }^{22}$

Mekanisme antibakteri dari bakteriosin adalah sebagai berikut: 1) kontak langsung bakteriosin dengan membran sel dan menyebabkan destabilitas dari membran sel bakteri sehingga sel menjadi tidak kuat, 2) ketidakstabilan membran tersebut dapat membentuk lubang dan pori pada sel membran dan menyebabkan kebocoran dan mengganggu aktivitas keluar masuknya molekul seluler, 3) kedua hal sebelumnya akan menyebabkan penurunan $\mathrm{pH}$ seluler secara gradien. Seluruh fenomena yang telah disebutkan akan menyebabkan terhambatnya pertumbuhan sel hingga menghasilkan proses kematian dari sel bakteri. 25

Zat lainnya yaitu hidrogen peroksida sebagai hasil produksi alat pelindung diri yang bersifat bakteriostatik serta bakterisidal. Aktivitas dari hidrogen peroksida tidak dipengaruhi oleh tingkat keasaman dari produk susu fermentasi. Hidrogen peroksida menyebabkan perubahan pada sistem enzim pada sel bakteri dan dapat dijadikan zat antimikroba melawan bakteri, fungi hingga virus. ${ }^{26}$

Hasil yang didapatkan dari penelitian ini walaupun nilai KHM dan KBM yang tidak berbeda diantara keduanya, tetapi berdasarkan jumlah koloni E.coli, kefir susu sapi memiliki daya hambat yang lebih kuat dibandingkan kefir susu kambing. Hasil penelitian ini berbeda dengan penelitian yang dilakukan oleh Suhartanti dalam membandingkan aktivitas antibakteri kefir susu kambing dan kefir susu sapi terhadap Bacillus cereus serta Staphylococcus aureus. Berdasarkan hasil nilai rerata, kefir susu kambing memiliki daya hambat yang lebih kuat dibandingkan dengan kefir susu sapi.6,8 
Perbedaan hasil dengan penelitian lainnya dapat disebabkan oleh beberapa faktor. Kefir susu sapi yang digunakan dalam penelitian ini berusia lebih lama dibanding kefir susu kambing yang segar setelah produksi. Proses fermentasi kefir terjadi disaat biji kefir dimasukkan ke dalam susu segar, namun setelah dipisahkannya biji kefir dari produk hasil fermentasi berupa susu kefir, tetap terjadi proses fermentasi lanjutan yang dilakukan oleh BAL yang telah terbentuk pada produk susu akhir kefir. Silva et al melaporkan hasil penelitian dimana perpanjangan waktu fermentasi dari kefir akan meningkatkan aktivitas antibakteri dari kefir tersebut. $^{27}$ Hal tersebut sejalan dengan hasil observasi pada penelitian yang dilakukan Kim et $a l$, dalam membandingkan aktivitas antibakteri dari kefir. Kefir dengan usia lebih tua menunjukkan aktivitas antibakteri lebih kuat dalam menghambat berbagai bakteri patogen makanan. Hasil dari penelitian ini kefir sapi memiliki aktivitas antibakteri lebih kuat karena usia penyimpanan lebih lama dan aktivitas fermentasi lanjutan yang terjadi meningkatkan aktivitas antibakterinya. ${ }^{23}$

Bakteri asam laktat (BAL) pada kefir dalam menghambat bakteri patogen juga dipengaruhi oleh akumulasi berbagai asam organik yang diproduksinya. Asam-asam organik tersebut menyebabkan terjadinya penurunan $\mathrm{pH}$ dibawah kisaran $\mathrm{pH}$ pertumbuhan bakteri, kemudian berdifusi ke dalam sel bakteri patogen sehingga dapat menekan pertumbuhan bakteri patogen. Produk akhir susu fermentasi kefir memiliki BAL yang terus melakukan proses fermentasi lanjutan, hal itulah yang terjadi pada kefir susu sapi dalam penelitian ini dan menimbulkan akumulasi BAL serta asam organik lebih banyak dan menurunkan $\mathrm{pH}$, sehingga kefir susu sapi pada penelitian ini menunjukkan aktivitas antibakteri yang lebih kuat dibandingkan kefir susu kambing. Penyimpanan kefir sudah sesuai yaitu ditempatkan pada kondisi beku dengan suhu kurang dari $8^{\circ} \mathrm{C}$, namun disaat proses pencairan atau thawing dapat terjadi fermentasi lanjutan yang menyebabkan multiplikasi dari BAL pada kefir tersebut. ${ }^{28}$

Penurunan $\mathrm{pH}$ pada hasil akhir susu fermentasi kefir tidak hanya dipengaruhi oleh asam organik yang dihasilkan, tetapi juga dari kadar karbohidrat pada jenis susu yang digunakan. Kandungan karbohidrat berpengaruh pada susu fermentasi karena karbohidrat merupakan substrat utama yang digunakan oleh bakteri asam laktat untuk memfermentasikan susu. Hidrolisa dari karbohidrat yang dilakukan oleh asam organik maupun enzim akan meyebabkan penurunan $\mathrm{pH}$, sehingga semakin tinggi kadar karbohidrat pada suatu jenis susu, dapat mempengaruhi aktivitas antibakterinya yang disebabkan banyaknya karbohidrat yang dihidrolisis dan menyebabkan semakin rendahnya $\mathrm{pH}$ akhir dari produk susu fermentasi tersebut. Laktosa merupakan karbohidrat utama dalam susu, kandungan laktosa pada susu kambing 5,1gr/100 gr, sedangkan pada susu sapi sebesar 4,9gr/100 gr. Kandungan karbohidrat dari susu kambing dan susu sapi tidaklah berbeda jauh.29,30

Aktivitas antibakteri dari kefir tidak hanya bergantung pada tingkat keasaman $\mathrm{pH}$ serta asam-asam organiknya. Senyawa antibakteri yang bekerja menghambat bakteri tidak hanya asam organik yang bekerja pada kondisi asam, tetapi juga terdapat hidrogen peroksida serta bakteriosin yang menghambat bakteri pada kondisi netral. ${ }^{30}$

\section{Simpulan}

Berdasarkan hasil dari penelitian yang telah dilakukan, dapat disimpulkan bahwa terdapat KHM dan KBM pada tiap varian pengenceran dari kefir susu kambing dan kefir susu sapi. Tetapi tidak terdapatnya perbedaan daya hambat berupa KHM dan KBM antara kefir susu kambing dan kefir susu sapi. Secara nilai rerata dan berdasarkan jumlah koloni E.coli, kefir susu sapi lebih baik dalam menghambat pertumbuhan E.coli.

\section{Ucapan Terima Kasih}

Ucapan terima kasih peneliti sampaikan kepada seluruh pihak yang membantu dalam menyelesaikan penelitian ini.

\section{Daftar Pustaka}

1. FAO/WHO. Guidelines for The evaluation of probiotics in food. Report of a joint FAO/WHO working group on drafting guidelines evaluation of probiotics in food. London, Ontario, Canada: World Health Organization. 2002.

2. Bahar B. Kefir minuman susu fermentasi. Jakarta: PT Gramedia Pustaka Utama; 2008.

3. Bourrie BC, Willing BP, Cotter PD. The Microbiota and Health Promoting Characteristics of the Fermented Beverage Kefir. Front Microbiol. 2016;7:647.

4. Farnworth ER. 2005. Kefir a complex probiotic. Food Sci Tech Bulletin Funct Foods. 2005;2:1-17.

5. Tamime AY. Fermented milks: a historical food with modern applications-a review. Eur J Clin Nutr. 2002;56:S2-S15. 
6. Suhartanti D, Iqbal M. Perbandingan Aktivitas Antibakteri Kefir Susu Sapi dan Kefir Susu Kambing Terhadap Bakteri Staphylococcus aureus. J Ekosains. 2014;6:71-6.

7. Ranadheera CS, Vidanarachchi JK, Rocha RS, Cruz AG, Ajlouni S. Probiotic delivery through fermentation: dairy vs. non-dairy beverages. Fermentation. 2017;3:67.

8. Suhartanti D, Septian R. Perbandingan aktivitas antibakteri kefir susu sapi dan kefir susu kambing terhadap bakteri Bacillus cereus. KESMAS. 2014;8:71-6.

9. Serafini F, Turroni F, Ruas-Madiedo P, Lugli GA, Milani C, Duranti S, et al. Kefir fermented milk and kefiran promote growth of Bifidobacterium bifidum PRL2010 and modulate its gene expression. Int J Food Microbiol. 2014;178:50-9.

10. Rodrigues KL, Carvalho JC, Schneedorf JM. Antiinflammatory properties of kefir and its polysaccharide extract. Inflammopharmacology. 2005;13:485-92.

11. Rodrigues KL, Caputo LR, Carvalho JC, Evangelista J, Schneedorf JM. Antimicrobial and healing activity of kefir and kefiran extract. Int J Antimicrob Agents. 2005;25:404-8.

12. Chen Z, Shi J, Yang X, Nan B, Liu Y, Wang Z. Chemical and physical characteristics and antioxidant activities of the exopolysaccharide produced by Tibetan kefir grains during milk fermentation. Int Dairy J. 2015;43:15-21.

13. Powell JE. Bacteriocins and bacteriocin producers present in kefir and kefir grains [thesis]. South Africa: Stellenbosch University; 2006.

14. Allocati N, Michele M, Mikhail FA, Carmine DI. Escherichia coli in Europe: an overview. Int J Environ Res Public Health. 2013;10:6235-54.

15. Gill HS, Guarner F. Probiotics and human health: a clinical perspective. Postgrad Med J. 2004;80:516-26.

16. Peterson BW, Sharma PK, Van der Mei HC, Busscher HJ. Bacterial cell surface damage due to centrifugal compaction. Appl Environ Microbiol. 2012;78:120-5.

17. Rickwood D, Ford T, Steensgaard J. Centrifugation: essential data. USA: John Wiley \& Sons; 1994. p 12.

18. Cappuccino JG. Microbiology: a laboratory manual, Natalie Sherman. $10^{\text {th }}$ ed. USA: Pearson Education Inc; 2014. p 137-42

19. Bibiana W. Analisa mikroba di laboratorium. PT. Raja Grafindo Persada; 1994. p 51.

20. Sulmiyati. Fahrodi DU. Said NS. Malaka R. Maruddin F. Potensi Antibakteri kefir susu kambing terhadap bakteri Escherichia coli ATCC 8739 dan Salmonella enterica subsp. enterica serovar typhimurium ATCC 14028 dengan metode difusi kertas cakram. Prosiding Seminar Nasional. 2018:274-81.

21. Widodo W. Bioteknologi industri susu. Yogyakarta: Lacticia Press; 2003:114.

22. Hafsan. Bakteriosin asal bakteri asam laktat sebagai biopreservatif pangan. Jurnal Teknosains. 2014;8:175-84.

23. Kim DH, Jeong D, Kim H, Kang IB, Chon JW, Song KY, Seo KH. Antimicrobial activity of kefir against various food pathogens and spoilage bacteria. Korean J Food Sci An. 2016;36:787-90.

24. Kim DH. Chon JW. Kang IB. Kim H. Kim HS. Song KY. Seo KH. Growth inhibition of Cronobacter sakazakii in experimentally contaminated powdered infant formula by kefir supernatant. J Food Prot. 2015;78:1651-5.

25. Pradana IP, Dewi SS, Wilson W. Aktivitas kefir dan isolat bakteri asam laktat dari kefir dalam

Qonita Syafrina menghambat pertumbuhan Salmonella typhi. Pros Sem Nas Mahasiswa Unimus. 2018;1:170-7.

26. Vesterlund S. Mechanism of probiotics: production of antimicrobial substances. In: Lee YK, Salminen S, editor. Handbook of Probiotics and Prebiotics. Hoboken (US): John Wiley \& Sons Inc; 2009.

27. Silva KR. Rodrigues SA. Filho LX. Lima AS. Antimicrobial activity of broth fermented with kefir grains. Appl Biochem Biotechnol. 2009;152:316-25.

28. Yusliasni. Aktivitas antimikroba khamir asal dadih (susu kerbau fermentasi) terhadap beberapa bakteri patogen. Agripet. 2010;11:19-24.

29. Guetouache M, Guessas B, Medjekal S. Composition and nutritional value of raw milk. issues biol. Sci. Pharm. Res. 2014;2:115-22.

30. Ningsih AS, Ekowati CN, Sumardi, Farisi S. Uji daya antibakteri isolat bakteri asam laktat dari kefir dengan inokulum ragi tape terhadap Escherichia coli. Jurnal Tadris Pendidikan Biologi. 2018;9:28-42.

31. Prudencio CV, Santos MT, Vanetti MD.Strategies for the use of bacteriocins in gram-negative bacteria: Relevance in food microbiology. J Food Sci Technol. 2015;52:5408-17. 